\title{
Role of the fetal pituitary in cryptorchidism induced by exogenous maternal oestrogen during pregnancy in mice
}

\author{
C. A. Grocock, H. M. Charlton and M. C. Pike* \\ Department of Human Anatomy, South Parks Road, Oxford OX1 3QX, U.K. and*Imperial Cancer \\ Research Fund, Cancer Epidemiology Unit, Radcliffe Infirmary, Oxford OX2 6HE, U.K.
}

\begin{abstract}
Summary. A single subcutaneous injection of 5 or $1 \mathrm{mg}$ oestradiol given to pregnant female mice on Day 14 of pregnancy resulted in all male offspring being cryptorchid. Pituitary LH content, testicular weights and structure, seminal vesicle weights and the structure of the reproductive tract as a whole were monitored on the day of birth and at 2, 4, 8 and 14 weeks of age. Apart from an initial significant reduction in pituitary LH at the time of birth, no other marked differences were seen between control and treated animals except that all oestrogen-treated males lacked a gubernaculum and the testes were freely mobile within the abdomen. Hypogonadal ( $h p g$ ) male mice lacking GnRH are cryptorchid but have a normal gubernaculum and their testes develop and descend normally if treated with gonadotrophins. When the mothers of $h p g$ mice were treated with oestradiol the male offspring lacked a gubernaculum. These results indicate that perturbations of the fetal hypothalamic/pituitary axis play no significant part in oestrogen-induced cryptorchidism in mice.
\end{abstract}

Keywords: cryptorchidism; gubernaculum; maternal; oestrogen; LH; mouse

\section{Introduction}

The number of operations (orchidopexies) to correct cryptorchidism more than doubled in England and Wales in the period from 1962 to 1981 (Chilvers et al., 1984). On the basis of detailed analysis of the orchidopexy figures the authors estimated that the cumulative orchidopexy rate (from birth to 15 years of age) rose from 1.4\% for boys born in 1952 to $2.9 \%$ for those born in 1977. A large cohort study of newborn boys in Oxford has now confirmed this increase (John Radcliffe Hospital Cryptorchidism Study Group, 1986a, b). An increased incidence of cryptorchidism gives cause for concern not only because of the morbidity associated with orchidopexy, but also because the affected males are at a much increased risk both in developing a malignant testicular germ-cell tumour and of being infertile (Chilvers et al., 1986).

Although the causes of this increase are likely to be multifactorial, there are some epidemiological data suggesting that exposure of the fetus to exogenous oestrogen increases the incidence both of cryptorchidism and of testicular cancer; and there is also circumstantial evidence that elevated circulating maternal oestrogens during pregnancy may have the same effects (Depue et al., 1983; Depue, 1984). Exposure of pregnant female mice to high levels of oestrogen (5 mg oestradiol dipropionate) on Day 14 of pregnancy results in a very high proportion of cryptorchid male offspring (Raynaud \& Raynaud, 1958; Jean, 1973); we therefore have a convenient animal model of oestrogen-induced cryptorchidism in man.

Hadziselimovic \& Girard (1977) proposed that the failure of testicular descent in oestrogentreated mice was due to an action of the maternally injected oestrogen upon the hypothalamus and/or pituitary of the embryo leading to impaired androgen secretion by the fetal testis. They also 
suggested, based on their finding of altered Leydig cell morphology and reduced testicular testosterone content in the adult cryptorchid mouse, that the effect on hypothalamic/pituitary function was long lasting. However, Hadziselimovic \& Girard (1977) made no direct measurements of hypothalamic/pituitary function although they did demonstrate reduced testicular testosterone content in adult cryptorchid mice. Suzuki \& Arai (1986), in a paper on the effects of diethylstilboestrol on the gubernaculum, again stressed that the current hypothesis is that oestrogens inhibit testicular descent through the suppression of the pituitary-gonadal axis. They suggested that there might be a direct effect of diethylstilboestrol on the gubernaculum and further study is needed to determine the site of oestrogen action.

In the hypogonadal $(\mathrm{hpg})$ mouse a deletion in the gene encoding hypothalamic gonadotrophic hormone-releasing hormone $(\mathrm{GnRH})$ results in a failure in pituitary gonadotrophic hormone synthesis and secretion. The $h p g$ mice are cryptorchid and testicular development is arrested at birth. However, treatment of hpg adults with testosterone or with brain grafts of CNS tissue containing normal GnRH neurones results in testicular descent and near normal development of the testes (Charlton, 1986). Cryptorchidism in the hpg mouse is thus entirely due to a failure in the post-natal phase of testicular descent, which is critically dependent upon pituitary and testicular hormones (Rajfer \& Walsh, 1977). These observations on hpg mice show that defective fetal pituitary function will only result in cryptorchidism if the pituitary dysfunction extends into the adult life of the mouse. Fetal pituitary dysfunction alone will not result in cryptorchidism. Hadziselimovic \& Girard's (1977) proposed explanation for oestrogen-induced cryptorchidism depends critically therefore on a long-term defect in pituitary function in the male offspring.

We decided to investigate directly whether post-natal pituitary function was impaired in the male offspring of pregnant female mice treated with oestrogen, because Hadziselimovic \& Girard's (1977) finding of normal testicular weight in the fetal-oestrogen-induced cryptorchid mice argues strongly that these mice must have had, at some stage after birth, near normal pituitary function (and testosterone levels). We expected to find near normal pituitary function in these cryptorchid mice and so we also undertook, at the same time, a careful anatomical dissection of their reproductive tracts to try to identify any possible actions of the oestrogen on the reproductive tract that could explain the cryptorchidism.

\section{Materials and Methods}

Normal mice. The mice used in this study resulted from crossing the $\mathrm{F} 1$ hybrids between two inbred strains, $\mathrm{C} 3 \mathrm{H} / \mathrm{HeH}$ and $101 \mathrm{H}$. Females were mated and the day the vaginal plug was observed was counted as Day 1 of pregnancy. Pregnant females were injected subcutaneously on Day 14 with $5 \mathrm{mg}$ oestradiol- $17 \beta$ (Sigma Chemical Co. Ltd, Poole, Dorset, U.K.) dissolved in $0.2 \mathrm{ml}$ arachis oil (Exp. 1) or with $1 \mathrm{mg}$ oestradiol-17 $\beta$ dissolved in $0.2 \mathrm{ml}$ dimethylsulphoxide (DMSO; BDH Chemicals Ltd, Poole, Dorset, U.K.) (Exp. 2) or with the appropriate diluent (controls). It was found difficult to dissolve oestradiol in arachis oil at this level, so DMSO was used as the vehicle and a lower concentration $(1 \mathrm{mg}$ ) was found to be as effective as $5 \mathrm{mg}$ in oil (see below). After injection the females were caged individually. It was found necessary to perform Caesarean sections on all treated females and to foster the young, because the females failed to deliver normally. This was done on Day 20 of pregnancy. Male offspring were killed at birth or at 4,8 or 14 weeks of age (Exp. 1), or at birth or at 2, 4 or 8 weeks of age (Exp. 2).

At the time of killing the pituitary was removed and homogenized in $1 \mathrm{ml}$ phosphate-buffered saline, frozen and stored at $-20^{\circ} \mathrm{C}$ before radioimmunoassay for luteinizing hormone ( $\mathrm{LH}$ ) as described by Niswender et al. (1968) and ter Haar \& MacKinnon (1973) using the NIH-LH-S13 standard. Within- and between-assay coefficients of variation were $8 \%$ and $16 \%$ respectively. The sensitivity of the assay was $0 \cdot 25 \mathrm{ng} \mathrm{LH}-\mathrm{S} 13 / \mathrm{ml}$ at $90 \%$ binding. NIH-LH-S13 has an FSH contamination equivalent to 0.014 units NIH-FSH-S1/mg. Assay blank was minus antibody and had a value of $3.4 \%$ for non-specific binding as a percentage of total counts.

At autopsy, the structure of the reproductive tract was observed and the presence or absence of any structures noted; the testes were then removed, immersion-fixed in Karnovsky's fixative, weighed and processed for routine electron microscopy. Seminiferous tubule diameters (equivalent circle diameter, which is the diameter of a circle of equal area to that of the feature measured) were measured on $1 \mu \mathrm{m}$ resin sections stained with toluidine blue, using an interactive programme on the Kontron IBAS Image Analyser. Ten tubules were measured per testis and a mean value obtained for each animal. These mean values were then used to calculate means and standard errors 
for each experimental group. Seminal vesicles were removed and weighed to give an indication of androgen production.

Hypogonadal (hpg) mice. Females, heterozygous for the hpg gene, were crossed with hybrid males (as above). These females were treated in the same manner as described above for normal mice (Exp. 1). The male offspring were killed at 4 and 14 weeks of age.

Statistical methods. Statistical analyses were carried out using Student's $t$ test.

\section{Results}

\section{Pituitary LH content}

There was $71 \%$ suppression in pituitary $\mathrm{LH}$ content in those animals killed on the day of delivery in Exp. 1 (2-sided test, $P<0.01$ ), and a similar result was obtained in Exp. 2 (Table 1). The extent of this suppression had dropped to $20 \%$ by Week 8 in Exp. 1 and was no longer statistically significant. In Exp. 2, using only $1 \mathrm{mg}$ oestradiol, there was no evidence of LH suppression even as soon as 2 weeks after delivery.

Oestrogen-treated hpg males showed no significant differences from control hpg animals (mean pituitary $\mathrm{LH}$ was $216 \pm 36(\mathrm{~N}=5)$ and $189 \pm 44(\mathrm{~N}=3) \mathrm{ng} \mathrm{LH} /$ pituitary, respectively) at 14 weeks.

Table 1. Effect of oestradiol given on Day 14 of pregnancy on male offspring of normal mice at various ages

\begin{tabular}{|c|c|c|c|c|c|c|}
\hline $\begin{array}{l}\text { Post-natal } \\
\text { age } \\
\text { (weeks) }\end{array}$ & $\begin{array}{l}\text { Dose of } \\
\text { oestrogen } \\
\text { (mg) }\end{array}$ & $\begin{array}{l}\text { No. of } \\
\text { mice }\end{array}$ & $\begin{array}{l}\text { Wt of testis } \\
\text { (mg) }\end{array}$ & $\begin{array}{l}\text { Wt of seminal } \\
\text { vesicles (mg) }\end{array}$ & $\begin{array}{l}\text { Pituitary } \\
\text { LH content } \\
\text { (ng/gland). }\end{array}$ & $\begin{array}{c}\text { Seminiferous } \\
\text { tubule diam. } \\
\quad(\mu \mathrm{m})\end{array}$ \\
\hline 0 & $\begin{array}{l}5 \\
0\end{array}$ & $\begin{array}{l}18 \\
13\end{array}$ & $\begin{array}{l}0.71 \pm 0.03 \\
0.71 \pm 0.03\end{array}$ & - & $\begin{array}{l}4.9 \pm 0.5^{*} \\
16.8 \pm 3.8\end{array}$ & $\begin{array}{l}48.4 \pm 1.4 \\
51.1 \pm 2.8\end{array}$ \\
\hline 4 & $\begin{array}{l}5 \\
0\end{array}$ & $\begin{array}{l}10 \\
14\end{array}$ & $\begin{array}{l}42 \cdot 9 \pm 2 \cdot 1 \\
47 \cdot 8 \pm 2 \cdot 3\end{array}$ & $\begin{array}{l}5.7 \pm 1.2 \\
9.9 \pm 1.3\end{array}$ & $\begin{array}{l}-\dagger \\
-\dagger\end{array}$ & $\begin{array}{l}194 \pm 11.7 \\
190 \pm 7.5\end{array}$ \\
\hline 8 & $\begin{array}{l}5 \\
0\end{array}$ & $\begin{array}{r}6 \\
18\end{array}$ & $\begin{array}{l}66.6 \pm 6.8 \\
85.6 \pm 5.5\end{array}$ & $\begin{array}{r}91 \cdot 7 \pm 25.4 \\
97.7 \pm 6.9\end{array}$ & $\begin{array}{l}1227 \pm 121 \\
1533 \pm 112\end{array}$ & $\begin{array}{l}249 \pm 9 \cdot 4 \\
234 \pm 11 \cdot 5\end{array}$ \\
\hline 14 & $\begin{array}{l}5 \\
0\end{array}$ & $\begin{array}{r}8 \\
10\end{array}$ & $\begin{array}{l}83.0 \pm 10.4 \\
90.1 \pm 3.7\end{array}$ & $\begin{array}{r}82 \cdot 0 \pm 16 \cdot 4 \\
123 \cdot 6 \pm 10 \cdot 0\end{array}$ & $\begin{array}{l}1694 \pm 353 \\
2527 \pm 156\end{array}$ & $\begin{array}{l}233 \pm 12 \cdot 3 \\
243 \pm 8 \cdot 2\end{array}$ \\
\hline 0 & $\begin{array}{l}1 \\
0\end{array}$ & $\begin{array}{l}10 \\
10\end{array}$ & $\begin{array}{l}0.72 \pm 0.05 \\
0.68 \pm 0.04\end{array}$ & - & $\begin{aligned} & 5.4 \pm 0.7^{*} \\
& 19.8 \pm 4.9\end{aligned}$ & $\begin{array}{l}+ \\
-\dagger\end{array}$ \\
\hline 2 & $\begin{array}{l}1 \\
0\end{array}$ & $\begin{array}{l}10 \\
11\end{array}$ & $\begin{array}{l}12.9 \pm 1.1 \\
10.9 \pm 1.0\end{array}$ & $\begin{array}{l}1 \cdot 1 \pm 0.2 \\
1.9 \pm 0.3\end{array}$ & $\begin{array}{l}441 \pm 46 \\
360 \pm 39\end{array}$ & $\begin{array}{l}-\dagger \\
-\dagger\end{array}$ \\
\hline 4 & $\begin{array}{l}1 \\
0\end{array}$ & $\begin{array}{r}16 \\
7\end{array}$ & $\begin{array}{l}36.4 \pm 2.2 \\
49.6 \pm 2.9\end{array}$ & $\begin{array}{l}4 \cdot 1 \pm 0 \cdot 7 \\
5 \cdot 8 \pm 0 \cdot 5\end{array}$ & $\begin{array}{l}971 \pm 48 \\
981 \pm 97\end{array}$ & -+ \\
\hline 8 & $\begin{array}{l}1 \\
0\end{array}$ & $\begin{array}{l}13 \\
14\end{array}$ & $\begin{array}{l}86.2 \pm 8.2 \\
72 \cdot 7 \pm 2.4\end{array}$ & $\begin{array}{l}37 \cdot 9 \pm 6 \cdot 6^{* * *} \\
80 \cdot 1 \pm 5 \cdot 0\end{array}$ & $\begin{array}{l}2102 \pm 136 \\
1789 \pm 123\end{array}$ & $-\dagger$ \\
\hline
\end{tabular}

Values are mean \pm s.e.m.

+ Not measured.

${ }^{*} P<0.01 ;{ }^{* *} P<0.001$ compared with controls $(0 \mathrm{mg})$ of that age.

\section{Effects on the testes}

Festicular weights at delivery and later were very similar in control and experimental males (Table 1). No differences in seminiferous tubule diameters were noted either at delivery or later in Exp. 1 (Table 1). In addition, the histological appearance of the testes was similar in the oestrogen-treated and control groups. At 4 and 14 weeks oestrogen-treated hpg males had mean 

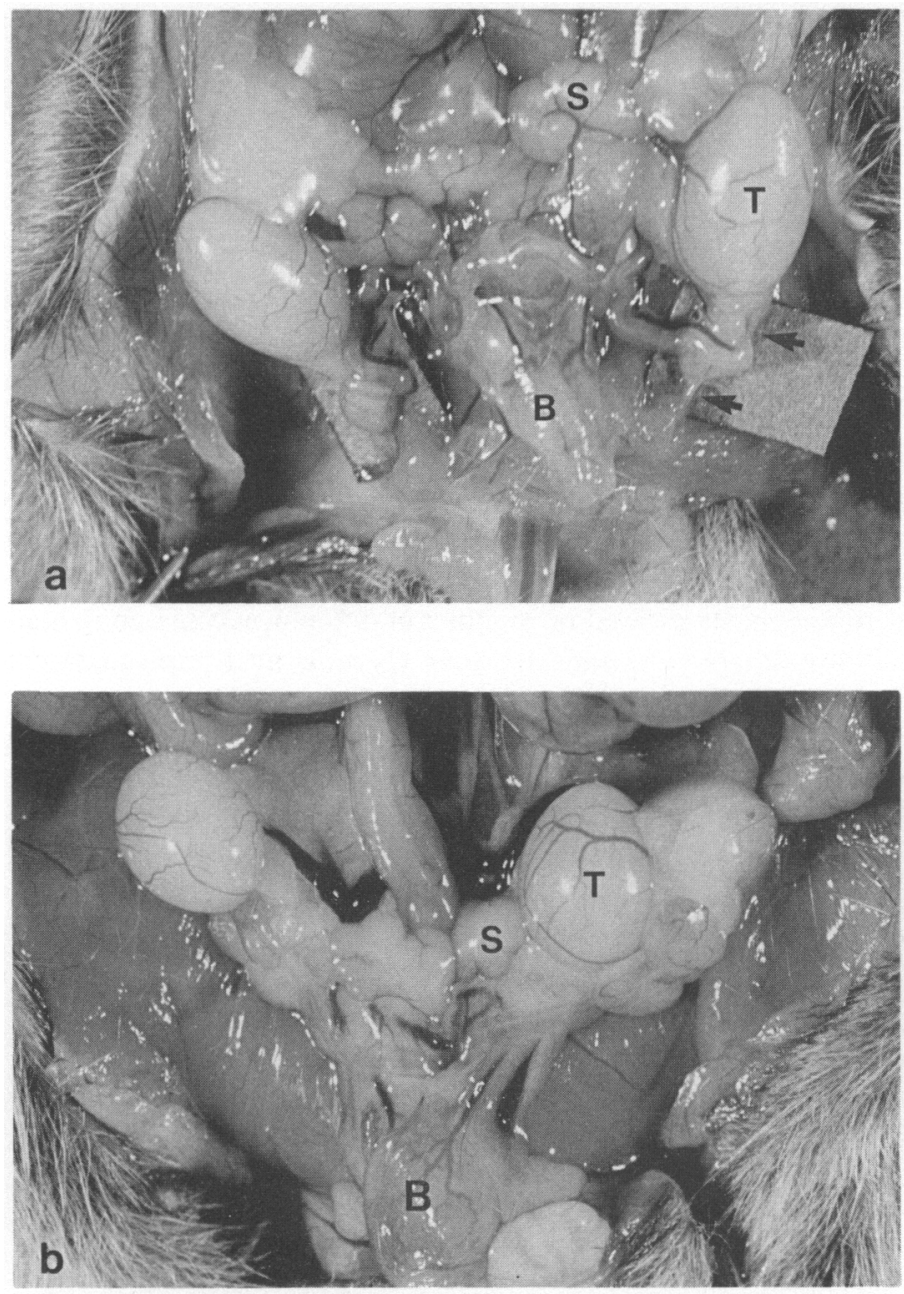

Fig. 1. Appearance of the reproductive tract of (a) a sexually mature normal male mouse showing well developed gubernaculum (arrows) and (b) an oestrogen-treated ( $1 \mathrm{mg}$ ) cryptorchid male of the same age showing complete absence of a gubernaculum. $\mathrm{T}=$ testis; $\mathrm{S}=$ seminal vesicle; $\mathbf{B}=$ bladder.

testicular weights of $2.4 \pm 0.1 \quad(\mathrm{~N}=7)$ and $2.7 \pm 0.2(\mathrm{~N}=5)$ mg per testis, respectively, compared to $1.9 \pm 0 \cdot 3(\mathrm{~N}=6)$ and $2 \cdot 6 \pm 0 \cdot 3(\mathrm{~N}=3) \mathrm{mg}$ per testis, respectively, for control hpg males.

\section{Effects on the reproductive tract}

There were marked differences in the reproductive tracts of oestrogen-treated and control males. In control animals the testes were descended by 4 weeks of age with a well-defined gubernaculum anchoring the testes to the inferior wall of the scrotum (Fig. 1a). In all oestrogentreated $(5 \mathrm{mg}$ or $1 \mathrm{mg}$ ) animals, both normal and hpg, the epididymis and vas deferens with associated blood vessels were attached to the testis but there was no sign of a gubernaculum attaching the cauda epididymidis to the scrotum (Fig. 1b). As a result the testes, although of a size and structure usually found in normal or hpg males, were freely mobile within the abdominal 
cavity. Sometimes one or both testes were found in the scrotum after 4 weeks of age, although they were not physically attached there. At other times both testes were found high in the abdomen, often on the same side of the body. Seminal vesicle weights increased with age in both oestrogentreated groups of normal males.

\section{Discussion}

The above experiments confirm that exposure of pregnant female mice to 1 or $5 \mathrm{mg}$ oestradiol results in cryptorchidism in $100 \%$ of the male offspring. This cryptorchidism is due to a failure of development of the gubernaculum and not to any long-term perturbations of the hypothalamic/ pituitary system. The transient depression in pituitary LH content seen only at the time of birth is probably due to a carry over effect of the oestrogen injected 6 days earlier. This observation would suggest that the development of the interrelationship between hypothalamic GnRH and pituitary gonadotrophic hormone synthesis and secretion in the fetus are likely to be aberrant exactly as suggested by Hadziselimovic \& Girard (1977). However, any depression of pituitary function is unlikely itself to affect the development of the gubernaculum because hypogonadal ( $\mathrm{hpg}$ ) mice are born with a perfectly normal gubernacular attachment to the scrotum. Treatment of heterozygous females carrying hpg embryos with oestrogen resulted in $h p g$ offspring with no gubernaculum, a further indication that depression of the gonadotrophic potency of the fetal pituitary is not directly involved in the oestrogen effect on cryptorchidism.

The effects of exogenous oestrogens other than oestradiol (or oestradiol benzoate) on the development of the reproductive tract have been well documented (Greene et al., 1940; McLachlan et al., 1975; McLachlan, 1981; Arai et al., 1983; Suzuki \& Arai, 1986). Diethylstilbestrol or other oestrogens (e.g. ethinyl oestradiol) have been shown to cause a suppression of spermatogenesis in young male mice, although with no effect on testicular weight (Takasugi et al., 1983), or reduced numbers of Sertoli cells (Yasuda et al., 1985). In the experiments reported in this paper there were no significant effects of the oestrogen treatment on spermatogenesis even at 14 weeks of age. Indeed, 3 cryptorchid males of this age were mated with normal females and pregnancies and litters resulted. The differences in effect on spermatogenesis may be due to a number of factors, e.g. differences in the type or dose of hormone used, susceptibility of different strains of mice to oestrogen or slight differences in the timing of administration of the hormones used. It has been suggested (Takasugi et al., 1983) that the reduced spermatogenic activity observed in 60-day-old male mice might be due to a permanent suppression of gonadotrophin secretion but, as in the study of Suzuki \& Arai (1986), no measurements of gonadotrophin concentrations were made. There are no significant differences in plasma concentrations of LH or FSH in human males exposed prenatally to diethylstilboestrol (Gill et al., 1981). Neonatal administration of oestrogen in rats produced only transient effects on LH and FSH values (Brown-Grant et al., 1975) with LH concentrations returning to control values some 2 weeks after treatment. Although the normal rise in FSH concentrations was delayed, coinciding with the delay in the onset of puberty, after 75 days of age spermatogenesis was similar in the experimental and control males.

In a recent comprehensive review of the mechanisms involved in testicular descent, Hutson \& Donahoe (1986) have suggested that oestrogens may interfere with Müllerian Inhibiting Substance (MIS). MIS has been suggested as the hormone responsible for the transabdominal phase of testicular descent. This suggestion is entirely consistent with the results reported here but the exact site and mode of action of the injected oestrogen remain equivocal. Injection of the hormone into the pregnant mother will obviously affect the maternal pituitary and probably markedly alter maternal ovarian function. Indeed, the fact that in all experiments presented here the young had to be delivered by Caesarean section is an indication of this. To reach the embryo the oestrogen will have to cross the placenta, another site where elevated circulating hormones could affect the fetal physiology. Any oestrogen which crosses the placenta could affect the fetal testis, perhaps inhibiting the production of a factor, which could be a steroid or even MIS, 
involved in development of the gubernaculum. Huseby (1980) when discussing the carcinogenic effects of oestrogen on the testis, suggested that there might be a direct effect at the level of the Leydig cells. It is also possible that there is a direct effect of oestrogen on the gubernaculum as suggested by Suzuki \& Arai (1986). Whatever mechanism is involved, the results reported above suggest that perturbation of the fetal hypothalamic/pituitary axis does not play an essential role.

This work was supported by the Imperial Cancer Research Fund who also financed partpurchase of the Kontron IBAS Image Analyser. We thank Carolyn Harrison and Philip Pledge for technical assistance; Dr Savile Bradbury and Ann Stanmore for image analysis measurements; and Dr Pamela MacKinnon and Bob Laynes for the hormone assays.

\section{References}

Arai, Y., Mori, T., Suzuki, Y. \& Bern, H.A. (1983) Longterm effects of perinatal exposure to sex steroids and diethylstilbestrol on the reproductive system of male mammals. Int. Rev. Cytol. 84, 235-268.

Brown-Grant, K., Fink, G., Greig, F. \& Murray, M.A.F. (1975) Altered sexual development in male rats after oestrogen administration during the neonatal period. J. Reprod. Fert. 44, 25-42.

Charlton, H.M. (1986) Use of neural transplants to study neuroendocrine mechanisms. In Frontiers in Neuroendocrinology, Vol. 9, pp. 77-97. Eds W. F. Ganong \& L. Martini. Raven Press, New York.

Chilvers, C., Pike, M.C., Forman, D., Fogelman, K. \& Wadsworth, M.E.J. (1984) Apparent doubling of frequency of undescended testis in England and Wales in 1962-81. Lancet 2, 330-332.

Chilvers, C., Dudley, N.E., Gough, M.H., Jackson, M.B. \& Pike, M.C. (1986) Undescended testis: the effect of treatment on subsequent risk of sub-fertility and malignancy. J. Ped. Surg. 21, 691-696.

Depue, R.H. (1984) Maternal and gestational factors affecting the risk of cryptorchidism and inguinal hernia. Int. J. Epidem. 13, 311-318.

Depue, R.H., Pike, M.C. \& Henderson, B.E. (1983) Estrogen exposure during gestation and risk of testicular cancer. J. natn. Cancer Inst. 71, 1151-1155.

Gill, W.B., Schumacher, G.F.B., Hubby, M.M. \& Blough, R.R. (1981) Male genital tract changes in humans following intrauterine exposure to diethylstilbestrol. In Developmental Effects of Diethylstilbestrol (DES) in Pregnancy, pp. 103-119. Eds A. L. Herbst \& H. A. Bern. Thieme-Stratton, New York.

Greene, R.R., Burrill, M.W. \& Ivy, A.C. (1940) Experimental intersexuality. The effects of estrogens on the antenatal sexual development of the rat. Am. J. Anat. 67, 305-345.

Hadziselimovic, F. \& Girard, J. (1977) Pathogenesis of cryptorchidism. Horm. Res. 8, 76-85.

Huseby, R.A. (1980) Demonstration of a direct carcinogenic effect of estradiol on Leydig cells of the mouse. Cancer Res. 40, 1006-1013.

Hutson, J.M. \& Donahoe, P.K. (1986) The hormonal control of testicular descent. Endocr. Revs. 7, 270-283.

Jean, C. (1973) Croissance et structure des testicules cryptorchides chez les souris nées de meres traitées a l'oestradiol pendant la gestation. Annls Endocr. 34, 669-687.

John Radcliffe Hospital Cryptorchidism Study Group (1986a) Boys with late descending testes-the source of 'retractile' testes undergoing orchidopexy. Br. med. J. 293, 789-790.

John Radcliffe Hospital Cryptorchidism Study Group (1986b) Cryptorchidism: an apparent substantial increase since 1960. Br. med. J. 293, 1401-1404.

McLachlan, J.A. (1981) Rodent models for perinatal exposure to diethylstilbestrol and their relation to human disease in the male. In Developmental Effects of Diethylstilbestrol (DES) in Pregnancy, $\mathrm{pp}$. 149-157. Eds A. L. Herbst \& H. A. Bern. ThiemeStratton, New York.

MaLachlan, J.A., Newbold, R.R. \& Bullock, B. (1975) Reproductive tract lesions in male mice exposed prenatally to diethylstilbestrol. Science, N.Y. 190, 991-992.

Niswender, G.D., Midgley, A.R., Monroe, S.E. \& Reichert, L.E. (1968) Radio-immunoassay for rat luteinizing hormone with anti-ovine LH serum and ovine LH $\left[{ }^{134} \mathrm{I}\right]$. Proc. Soc. exp. Biol. Med. 128, 807-811.

Rajfer, J. \& Walsh, P.C. (1977) Hormonal regulation of testicular descent: experimental and clinical observations. J. Urol. 118, 985-990.

Raynaud, A. \& Raynaud, J. (1958) Effects sur l'appareil gubernaculaire des foetus des hormones oestrogenes injectees a la souris gravide. C. r. Séanc Soc. Biol. 152, 1461-1464.

Suzuki, Y. \& Arai, Y. (1986) Possible linkage between developmental disorder of the gubernaculum testis and cryptorchidism in male mice exposed prenatally to diethystilbestrol. Proc. Japan Acad., Ser. B. 62, 412-415.

Takasugi, N., Tanaka, M. \& Kato, C. (1983) Effects of continuous intravenous infusion of diethylstilbestrol into pregnant mice on fetus: testicular morphology at fetal and postnatal period. Endocrinol. Japon. 30, $35-42$.

ter Haar, M.B. \& Mackinnon, P.C.B. (1973) Changes in serum gonadotrophin levels, and in protein levels and in-vivo incorporation of $\left[{ }^{35} \mathrm{~S}\right]$ methionine into protein of discrete brain areas and the anterior pituitary of the rat during the oestrous cycle. J. Endocr. 58, $563-576$

Yasuda, Y., Kihara, T. \& Tanimura, T. (1985) Effect of ethinyl estradiol on the differentiation of mouse fetal testis. Teratology 32, 113-118. 